\title{
Effect of Different Modes of Light Modulation on the Bond Strength and Knoop Hardness of a Dental Composite
}

\author{
Eduardo DALLl'MAGRO' \\ Mário Alexandre Coelho SINHORETI ${ }^{1}$ \\ Américo Bortolazzo CORRER ${ }^{1}$ \\ Rafael Leonardo Xediek CONSANI ${ }^{2}$ \\ Eliseu Augusto SICOLI ${ }^{3}$ \\ Marcio José MENDONÇA ${ }^{3}$ \\ Lourenço CORRER-SOBRINHO ${ }^{1}$
}

\author{
${ }^{1}$ Dental Materials Area, Department of Restorative Dentistry, \\ Dental School of Piracicaba, State University of Campinas, Piracicaba, SP, Brazil \\ ${ }^{2}$ Prosthodontics Area, Department of Prosthodontics and Periodontics, \\ Dental School of Piracicaba, State University of Campinas, Piracicaba, SP, Brazil \\ ${ }^{3}$ Department of Prosthodontics, Dental School, Western Paraná University, Cascavel, PR, Brazil
}

\begin{abstract}
This study evaluated the bond strength and Knoop hardness of Z250 composite resin, light activated with XL2500 curing unit, using different protocols: continuous mode - high intensity $(\mathrm{CH})\left(700 \mathrm{~mW} / \mathrm{cm}^{2}\right)$ for $20 \mathrm{~s}$; continuous mode - low intensity (CL) (150 mW/ $\mathrm{cm}^{2}$ ) for $20 \mathrm{~s}$; and pulse-delay with $150 \mathrm{~mW} / \mathrm{cm}^{2}$ for 2(P2), 3(P3), 5(P5), 10(P10) or $15 \mathrm{~s}$ (P15), with a 1-min delay, followed by 700 $\mathrm{mW} / \mathrm{cm}^{2}$ for $20 \mathrm{~s}$. For the push-out test $(\mathrm{n}=10)$, the bond strength values were obtained using a universal test machine at a crosshead speed of $0.5 \mathrm{~mm} / \mathrm{min}$. For Knoop hardness $(\mathrm{n}=5)$, the specimens were made using the same light-activation protocols. The hardness measurements were made with a hardness tester at six depths (top, 1, 2, 3, 4, and $5 \mathrm{~mm}$ ). The data were subjected to ANOVA and Tukey's test at 5\% significance level. For bond strength, CL and P5 presented significantly higher mean values $(\mathrm{p}<0.05)$ than the other groups. There was no statistically significant difference ( $>0.05)$ between P2, P3, P10, P15 and CH. For Knoop hardness, CH and P15 presented the highest mean values from top surface up to $4 \mathrm{~mm}$ depth, while CL presented the lowest hardness mean values ( $\mathrm{p}<0.05$ ). From the depth of $3 \mathrm{~mm}$ to $5 \mathrm{~mm}$, the mean values of all groups were significantly lower $(\mathrm{p}<0.05)$ than those recorded on top surface. In conclusion, for the pulse-delay method, the initial exposure time can influence bond strength and Knoop hardness of composites.
\end{abstract}

Key Words: dental composite, bond strength, Knoop hardness, pulse-delay.

\section{INTRODUCTION}

Composite resins are the most used direct restorative materials in dentistry. At present, dental composites are expected to have optical and mechanical properties comparable to those of tooth enamel and dentin and provide a service life of 10 years or more. However, polymerization shrinkage continues to be the primary problem of dental composites. Shrinkage is inherent to currently available adhesive systems and will persist until non-shrinking or low-shrinkage polymers (1) or expanding fillers are available in commercial composites. Shrinkage creates stress and marginal gap, leading to invasion of oral fluids and bacteria (2).

However, several factors limit the performance of composites, especially depth of cure and degree of conversion (DC). Light of an appropriate wavelength initiates light polymerization of methacrylate groups

Correspondence: Prof Dr. Lourenço Correr-Sobrinho e Prof. Dr. Mário Alexandre Coelho Sinhoreti, Faculdade de Odontologia de Piracicaba, UNICAMP, Área Materiais Dentários, Avenida Limeira, 901, 13414-903 Piracicaba, SP, Brasil. Tel: +55-19-2106-5348. Fax: +55-19-2106-5218. e-mail: sobrinho@fop.unicamp.brou sinhoret@fop.unicamp.br 
producing a highly cross-linked polymer matrix. Light from the curing source must be able to adequately polymerize deeper composite regions rather than only the top, irradiated surface. However, as light passes through the composite, it is absorbed and scattered, reducing its effectiveness to initiate polymerization, and consequently resulting in variation of depth of cure (3). Although high light intensity provides higher DC values, it also produces greater polymerization shrinkage, which may cause gap formation and further microleakage, compromising the longevity of the restoration (4). Another problem with insufficient polymerization is that a high amount of residual monomers may be released during the first days under oral conditions (5). The unreacted monomers result in inferior physical properties.

Several methods of light modulation have been used to light activate composites with the aim of minimizing the stress generated by polymerization shrinkage. These light activation methods have been suggested to initiate the composite cure reactions and maintain DC values similar to those found when using high light intensity, whilst reducing the polymerization shrinkage. Soft-start polymerization and pulse-delay polymerization adopt an initially low light intensity followed by a final cure with high light intensity. A slower rate of conversion allows for better flow of the material, which, in turn, decreases shrinkage stresses, leading to better marginal adaptation. The complement of light activation with high irradiance is intended to allow the composite to achieve the maximum DC (6). Irradiance diminishes as the curing tip is moved away from the composite restorative material (7), this approach can be used for two-step light activation methods.

Furthermore, the viscoelastic nature of the polymerizing composite must also be considered. During polymerization, there is an irreversible increase in composite elastic modulus. The moment the loss of the flowing capacity of the material occurs is called the gelpoint. Prior to the gel-point, polymerization shrinkage will not create stress at the restoration margins or within the material, as it is compensated by flow. However, rigid contraction after the gel-point has received much attention and has been reported to be responsible for the induction of stress in the bonding interface, demonstrating that the speed of the polymerization reaction has a great effect on stress generation (6).

The testing design for this study was a push-out model. Extrusion testing in dentistry was first described in 1970 by Roydhouse (8), who proposed pushing out dental material cylinders from tooth discs. Previous studies made use of a conical version of the push-out design, demonstrating the different bonding properties of direct and indirect restorations with highly reproducible measurements (9). Moreover, the cavity-like configuration of the bonding area allows the determination of both composite bond strength and marginal adaptation in the same sample (9).

Irrespective of the light activation method, DC must be as high as possible, ensuring that the material has the best properties. It has been demonstrated a good correlation between DC and hardness of composites, hence, hardness is used as an indicator of DC (10).

Adequate polymerization is required for clinically successful restorations. The ideal exposure time with low irradiance in the initial light exposure for two-step polymerization methods is primordial for optimal marginal adaptation and mechanical properties of composite resins. The objective of this study was to evaluate the influence of initial light exposure time variations, using pulse-delay light activation methods, on bond strength (push-out test) and Knoop hardness of a resin composite. The tested hypothesis was that initial exposure times of modulated curing methods provide a significant effect on bond strength with no reduction in the hardness of the restorative composite.

\section{MATERIAL AND METHODS}

Filtek Z250 composite resin (3M/ESPE, St.Paul, MN, USA; shade A3) was used in this study for analysis of bond strength and Knoop hardness.

\section{Push-Out Test}

Seventy 3-mm-high round metal molds were used, containing a truncated-cone cavity with a lower diameter of $6 \mathrm{~mm}$ and upper diameter of $9 \mathrm{~mm}$.

These molds were internally sandblasted with 40 $\mu \mathrm{m}$ aluminum oxide particles using a micro-etcher (Danville Engineering Inc., Danville, CA, USA). After sandblasting, the matrices were etched with $37 \%$ phosphoric acid for $15 \mathrm{~s}$, water rinsed and dried. The bonding agent silane (Ceramic Primer; 3M/ESPE) was applied and dried for $5 \mathrm{~s}$. The adhesive system (Adper Single Bond 2; 3M/ESPE) was applied, air-dried for $20 \mathrm{~s}$ and light activated for $10 \mathrm{~s}$ using a quartz tungsten halogen 
(QTH) light-curing unit (XL2500; 3M/ESPE).

During the application of resin composite the molds were set on a polyester strip positioned on a glass slab. The resin composite was bulk inserted and then covered with another polyester strip and pressed with a microscope sheet to accommodate the material into the matrix and remove composite excesses.

Composites were light-cured during $20 \mathrm{~s}$ with the QTH light-curing unit with $700 \mathrm{~mW} / \mathrm{cm}^{2}$ irradiance, as checked with a radiometer (Demetron Research Corp., Danbury, CT, USA). The specimens were light activated according to the following methods: continuous high irradiance mode $\left(700 \mathrm{~mW} / \mathrm{cm}^{2}\right.$ for $\left.20 \mathrm{~s}\right)(\mathrm{CH})$; continuous low irradiance mode $\left(150 \mathrm{~mW} / \mathrm{cm}^{2}\right.$ for $20 \mathrm{~s}$.) (CL); pulse-delay $\left(150 \mathrm{~mW} / \mathrm{cm}^{2}\right.$ for $2 \mathrm{~s}, 1$-min delay, followed by $700 \mathrm{~mW} / \mathrm{cm}^{2}$ for $\left.20 \mathrm{~s}\right)(\mathrm{P} 2)$; pulse-delay $(150 \mathrm{~mW} /$ $\mathrm{cm}^{2}$ for $3 \mathrm{~s}, 1-\mathrm{min}$ delay, followed by $700 \mathrm{~mW} / \mathrm{cm}^{2}$ for $20 \mathrm{~s})$ (P3); pulse-delay $\left(150 \mathrm{~mW} / \mathrm{cm}^{2}\right.$ for $5 \mathrm{~s}, 1$-min delayn, followed by $700 \mathrm{~mW} / \mathrm{cm}^{2}$ for $20 \mathrm{~s}$ ) (P5); pulsedelay $\left(150 \mathrm{~mW} / \mathrm{cm}^{2}\right.$ for $10 \mathrm{~s}, 1-\mathrm{min}$ delay, followed by $700 \mathrm{~mW} / \mathrm{cm}^{2}$ for $\left.20 \mathrm{~s}\right)(\mathrm{P} 10)$; pulse-delay $(150 \mathrm{~mW} /$ $\mathrm{cm}^{2}$ for $15 \mathrm{~s}, 1$-min delay, followed by $700 \mathrm{~mW} / \mathrm{cm}^{2}$ for $20 \mathrm{~s})$ (P15). For reduced irradiances, the tips of curing units were moved away from composite surfaces. In order to standardize the light activation distance, acrylic resin spacers (JET, Clássico Artigos Odontológicos, São Paulo, SP, Brazil) were interposed between the composite surface and the light-curing unit tip.

After light activation, the specimens were stored in an incubator at $37^{\circ} \mathrm{C} \pm 1$ for $24 \mathrm{~h} \pm 1$, in a dark and dry container, before the push-out test. The top and bottom surfaces of restorations were ground using \#400-grit abrasive papers (Carborundum, Saint-Gobain Abrasivos Ltda., PE, Brazil) in an automated polisher under water cooling to remove the composite excess and ensure correct specimen positioning on testing.

For the push-out test, an acrylic resin apparatus with a central hole was attached to a universal testing machine (Instron model 4411; Instron Corporation, Canton, MA, USA). A sphere-shaped rod fixed to a compression load cell of $500 \mathrm{~N}$ was used to load the composite restorations until failure at a crosshead speed of $0.5 \mathrm{~mm} / \mathrm{min}$. Push-out bond strength was determined by computing the quotient of maximum load $(\mathrm{N})$ and adhesion area (equation for calculation of truncated cones; $\mathrm{mm}^{2}$ ). Data were subjected to one-way ANOVA followed by Tukey's post-hoc test at a significance level of $5 \%$.

\section{Knoop Hardness Test}

For the Knoop hardness test, one metal mold ( 5 $\mathrm{mm}$ height $\mathrm{x} 5 \mathrm{~mm}$ diameter) was used to obtain 70 specimens. The composite resin was bulk inserted. A polyester strip was placed on surface of the specimen and pressed manually to remove composite excesses. Composite specimens were light-cured the QTH lightcuring unit, as described for the push-out test.

The specimens were stored in incubator at $37^{\circ} \mathrm{C}$ \pm 1 for $24 \mathrm{~h} \pm 1$, in a dark and dry container. After 24 $\mathrm{h}$ had elapsed, the specimens were embedded in polystyrene resin, and were ground and polished using \#320-, \#400-, \#600- and \#1,200-grit abrasive papers on an automated polisher under water-cooling. The specimens were dried and submitted to Knoop hardness measurements in a hardness tester (HMV 2; Shimadzu, Kyoto, Japan) with load of $50 \mathrm{~g}$ for $15 \mathrm{~s}$. Knoop hardness readings were taken on the top surface, 1, 2, 3,4 and $5 \mathrm{~mm}$ depth. For each depth, five readings were taken and averaged to obtain a mean value.

Data were subjected to one-way ANOVA followed by Tukey's post-hoc test at 5\% significance level.

\section{RESULTS}

\section{Push-Out Bond Strength}

Table 1 shows the means and standard deviations for bond strength results. P5 group revealed significantly higher bond strength $(p<0.05)$ than the

Table 1. Push-out bond strength means and standard deviation for resin composite Z250 photo-activated using different photoactivation methods and exposure times.

\begin{tabular}{ccc}
\hline Group & Exposure time (s) & Bond strength (MPa) \\
\hline P2 & $2+20$ & $05.40(1.89) \mathrm{c}$ \\
P3 & $3+20$ & $06.38(1.16) \mathrm{c}$ \\
P5 & $5+20$ & $34.20(8.47) \mathrm{a}$ \\
P10 & $10+20$ & $07.80(2.33) \mathrm{c}$ \\
P15 & $15+20$ & $06.12(1.73) \mathrm{c}$ \\
CL & 20 & $18.09(3.35) \mathrm{b}$ \\
CH & 20 & $04.87(0.87) \mathrm{c}$ \\
\hline
\end{tabular}

Means followed by different letters indicate statistically significant difference at $5 \%$ by Tukey's test. 
other groups. Specimens that were light activated using continuous mode with low irradiance $(\mathrm{CL})$ presented significantly lower bond strength $(\mathrm{p}<0.05)$ than those in P5 group, but significantly higher bond strength $(\mathrm{p}<0.05)$ than the other groups. There was no statistically significant difference among the P2, P3, P10, P15 and $\mathrm{CH}$ groups.

\section{Knoop Hardness}

Table 2 shows the Knoop hardness means and standard deviations. From the top surface up to $4 \mathrm{~mm}$ depth, $\mathrm{CH}$ and $\mathrm{P} 15$ groups presented the highest Knoop hardness means and differed significantly from P2 and CL groups $(p<0.05)$. Specimens that were light activated using continuous mode with low irradiance (CL) presented the lowest Knoop hardness means $(\mathrm{p}<0.05)$. There were no statistically significant differences among P3, P5, P10 and CH groups at any depth. Specimens of P2 group presented significantly lower Knoop hardness means than those of $\mathrm{CH}$ group at the top surface, 1, 2, 3 , and $4 \mathrm{~mm}$ depths. At $5 \mathrm{~mm}$, the composites of CL group were too soft for Knoop hardness testing (mean $0.00)$. There were no statistically significant differences among the other groups.

In Table 2, comparisons in the rows show that at $2 \mathrm{~mm}$ depth the Knoop hardness of P2, P5, P10, and CL groups, was significantly lower $(p<0.05)$ than that of the top surface. At $3 \mathrm{~mm}$ depth, the Knoop hardness of all groups was significantly lower $(p<0.05)$ than that of the top surface.

\section{DISCUSSION}

The tested hypothesis was that the initial exposure times of modulated curing methods had a significant effect on bond strength with no reduction in the hardness of the restorative composite. This hypothesis was accepted. In the present study, the pulse-delay technique led to an increase in bond strength when compared to continuous high irradiance. Specimens light cured with the pulse delay technique for $5 \mathrm{~s}$ during the initial cycle presented the highest bond strength. Curing time plays an important role in assessing stresses produced during the polymerization shrinkage of dental composites. High intensity light-curing units produce not only high hardness values, but also high shrinkage, making it important to balance the two effects by

Table 2. Knoop hardness means and SD Z250 composite resin light activated using different curing methods and exposure times.

\begin{tabular}{|c|c|c|c|c|c|c|c|}
\hline \multirow[t]{2}{*}{ Group } & \multirow{2}{*}{$\begin{array}{c}\text { Exposure } \\
\text { time }\end{array}$} & \multicolumn{6}{|c|}{ Depth (mm) } \\
\hline & & Top & 1 & 2 & 3 & 4 & 5 \\
\hline $\mathrm{P} 2$ & $2+20$ & $\begin{array}{c}55.07(2.57) \\
\text { b, A }\end{array}$ & $\begin{array}{c}51.75(2.73) \\
b, A B\end{array}$ & $\begin{array}{c}48.60(3.42) \\
\text { bc, } \mathrm{BC}\end{array}$ & $\begin{array}{c}44.71(2.70) \\
\text { b, CD }\end{array}$ & $\begin{array}{c}40.05(3.10) \\
\text { b, D }\end{array}$ & $\begin{array}{c}26.40(4.57) \\
\mathrm{a}, \mathrm{E}\end{array}$ \\
\hline P3 & $3+20$ & $\begin{array}{c}56.90(2.20) \\
\mathrm{ab}, \mathrm{A}\end{array}$ & $\begin{array}{c}55.66(1.97) \\
a b, A\end{array}$ & $\begin{array}{c}52.85(2.32) \\
\mathrm{ab}, \mathrm{AB}\end{array}$ & $\begin{array}{c}49.62(2.93) \\
a b, B\end{array}$ & $\begin{array}{c}44.03(2.27) \\
a b, C\end{array}$ & $\begin{array}{c}26.26(1.56) \\
\text { a, D }\end{array}$ \\
\hline P5 & $5+20$ & $\begin{array}{c}57.52(1.62) \\
a b, A\end{array}$ & $\begin{array}{c}55.30(1.69) \\
\mathrm{ab}, \mathrm{AB}\end{array}$ & $\begin{array}{c}51.02(1.60) \\
\mathrm{abc}, \mathrm{BC}\end{array}$ & $\begin{array}{c}48.91(1.75) \\
a b, C D\end{array}$ & $\begin{array}{c}44.53(1.03) \\
a b, D\end{array}$ & $\begin{array}{c}25.20(4.46) \\
\text { a, E }\end{array}$ \\
\hline $\mathrm{P} 10$ & $10+20$ & $\begin{array}{c}59.77(1.42) \\
a b, A\end{array}$ & $\begin{array}{c}55.00(1.41) \\
\mathrm{ab}, \mathrm{AB}\end{array}$ & $\begin{array}{c}51.03(2.19) \\
\text { abc, BC }\end{array}$ & $\begin{array}{c}47.57(2.28) \\
a b, C D\end{array}$ & $\begin{array}{c}44.04(0.87) \\
\mathrm{ab}, \mathrm{D}\end{array}$ & $\begin{array}{c}27.92(1.94) \\
\text { a, E }\end{array}$ \\
\hline $\mathrm{P} 15$ & $15+20$ & $\begin{array}{c}60.36(0.54) \\
a b, A\end{array}$ & $\begin{array}{c}57.77(1.30) \\
a b, A\end{array}$ & $\begin{array}{c}54.70(2.31) \\
\mathrm{a}, \mathrm{AB}\end{array}$ & $\begin{array}{c}51.05(2.06) \\
\mathrm{a}, \mathrm{BC}\end{array}$ & $\begin{array}{c}46.22(2.43) \\
\mathrm{a}, \mathrm{C}\end{array}$ & $\begin{array}{c}24.80(3.09) \\
\text { a, D }\end{array}$ \\
\hline $\mathrm{CL}$ & 20 & $\begin{array}{c}55.24(1.61) \\
\text { b, A }\end{array}$ & $\begin{array}{c}51.82(0.42) \\
\text { b, A }\end{array}$ & $\begin{array}{c}45.33(1.95) \\
\text { c, B }\end{array}$ & $\begin{array}{c}35.90(2.25) \\
\text { c, C }\end{array}$ & $\begin{array}{c}10.96(3.90) \\
\text { c, D }\end{array}$ & $\begin{array}{c}00.00(0.00) \\
b, E\end{array}$ \\
\hline $\mathrm{CH}$ & 20 & $\begin{array}{c}62.10(5.54) \\
\mathrm{a}, \mathrm{A}\end{array}$ & $\begin{array}{c}59.45(4.60) \\
\text { a, A }\end{array}$ & $\begin{array}{c}56.46(3.66) \\
\mathrm{a}, \mathrm{AB}\end{array}$ & $\begin{array}{c}53.00(2.76) \\
\mathrm{a}, \mathrm{BC}\end{array}$ & $\begin{array}{c}49.38(2.40) \\
\mathrm{a}, \mathrm{C}\end{array}$ & $\begin{array}{c}28.27(3.47) \\
\text { a, D }\end{array}$ \\
\hline
\end{tabular}

Means followed by different lowercase letters in columns and uppercase letters in rows indicate statistically significant difference at $5 \%$ by Tukey's test. 
selecting the correct curing time (11).

According to Sakaguchi et al. (12), the maximum contraction force rate occurs within the first $10 \mathrm{~s}$ of light activation. The contraction force can lead to rupture in the bond interface, decreasing bond strength. Therefore, if the polymerization rate can be controlled during the first $10 \mathrm{~s}$, a reduction in stress shrinkage may be obtained. Composite polymerization is a complex phenomenon that involves several factors. Polymerization shrinkage stress causes bond disruption, decreasing the bond strength values and increasing internal gap formation, especially under continuous light, in which the shrinkage stress is higher (13).

Stress develops almost immediately after polymerization is triggered, and most of the conversion occurs after the polymer matrix has reached a significant level of rigidity (14). The pulse-delay method described by Kanca and Suh (15) is based on the premise that a short pulse of light followed by a relaxation period in darkness allows the relief of stresses prior to inducing additional stresses during continuing polymerization, thus improving the marginal seal (12).

The rate of polymerization is influenced by the concentration of photo-initiators, monomer reactivity, molecular weight of monomer, leading to different viscosities and mobility (16). Moreover, characteristics related to light source, such as energy density and spectral flux, also alter final material properties (3).

It was observed that in addition to irradiance, the exposure time was very important in bond strength when the pulse-delay method was used. When the short exposure time was used ( $\mathrm{P} 2$ and $\mathrm{P} 3$ groups), the bond strength was similar to that of the $\mathrm{CH}$ group. Yap et al. (17) used the pulse-delay method in which the initial activation was carried out for $3 \mathrm{~s}$ at an intensity of 100 $\mathrm{mW} / \mathrm{cm}^{2}$, and they detected no shrinkage of the composite during light activation and the waiting period. This can be explained because the energy density applied during the first light activation cycle had been not enough to effectively initiate a polymerization reaction. Thus, all the shrinkage that the composite underwent was compensated for by the flow of the material. The reaction only became effective when the second high irradiance exposure occurred. Thus, the reaction occurred under high intensity with a similar reaction speed to that of the $\mathrm{CH}$.

For longer initial exposure times (P10 and P15 groups), bond strength values were similar to those of
$\mathrm{CH}$ group. The high energy density during the first curing cycle for P10 $\left(15.5 \mathrm{~J} / \mathrm{cm}^{2}\right)$ and P15 $(16.25 \mathrm{~J} /$ $\mathrm{cm}^{2}$ ) produced high conversion of double bonds, leading to high polymerization shrinkage and contraction force. This can be seen in the similar Knoop hardness results of the P10, P15 and $\mathrm{CH}$ groups.

When specimens were light activated using continuous low irradiance (CL), bond strength value was significantly lower than that of P5, but higher than the values of the other groups. At the low irradiance during the light activation cycle, the polymerization reaction occurred slowly, allowing the relief of shrinkage stresses, decreasing the stress in the bond interface. However, CL group presented the lowest Knoop hardness means. Hardness is an important parameter that has a bearing on the behavior of composite resin restorations in the oral environment. Irrespective of the light modulation method, it has been recommended that energy densities similar to those supplied by conventional light activation (continuous mode) should be used. This is recommended because previous studies related that the DC depends on the energy density that is supplied to the composite rather than the light activation method (18). Koran and Kurschner (6) found that the increase in density led to an increase in the hardness values in light activation with up to $17 \mathrm{~J} / \mathrm{cm}^{2}$, after which there was no significant alteration in hardness values. Specimens of CL group were light activated using the lowest energy density (3 $\left.\mathrm{J} / \mathrm{cm}^{2}\right)$. In this study, the maximum energy applied was when P15 $\left(16.25 \mathrm{~J} / \mathrm{cm}^{2}\right)$ was used. Therefore, the increase in bond strength of the CL group can be explained by the decrease in DC, leading to lower polymerization shrinkage stress. Groups that presented the lowest energy density (P2 and CL) showed statistically significant lower Knoop hardness means than $\mathrm{CH}$.

There were great differences between bond strength values. Push-out tests enable measurements of bond strength under more cavity-like conditions, demonstrating the properties of the restorative system better than in the shear or tensile tests. Confined spaces are less favorable from a mechanical perspective as a result of a high C-factor (2). Therefore, during polymerization more stresses occur, which pull the bonded restoration away from the dentin walls, creating stress at the toothrestorative interface (14). If shrinkage stress overcomes the bond strength, a gap may be formed at the adhesive interface. It was observed that specimens without gap formation presented high bond strength. 
However, when gap was present, there was an accentuated decrease in bond strength. The gaps are sites of stress concentration. During the push-out test, the stresses are focused on these sites, leading to rupture of the bond. In the specimens with no or less gap formation, the stresses are distributed throughout the bond interface, producing high bond strength values.

It has been hypothesized that when relatively few initiation centers are created by using continuous low irradiance, two-step or pulse-delay curing, the resulting polymer is less densely cross-linked, although the DC is not necessarily affected. As a result, the mechanical strength of the polymer is reduced and its susceptibility to degradation in organic solvents is increased (19). Gonçalves et al. (20) stated that DC and flexural strength after water storage of a composite resin were not affected by radiant exposure level or curing protocol. However, they suggested that the use of low irradiance or pulse-delay methods require a relatively high radiant exposure in order to originate a network structure similar to that obtained by continuous high irradiance light activation.

The bond strength of CL was significantly lower than that of P5. According to the results of this study, the relaxation period in darkness is of great importance for stress relief in composites. This implies that there could be a better relationship between exposure time and shrinkage stress than between exposure time and surface hardness. In other words, the exposure times influence the shrinkage force and stress values more than they influence surface hardness values. This makes it important for the dentist to minimize stresses at the tooth-restoration interface during restorative procedures.

Within the limitations of this study, it may be concluded that the initial light exposure time variations for pulse-delay light activation method had an influence on bond strength and Knoop hardness of Z250 composite resin. The P5 group $\left(150 \mathrm{~mW} / \mathrm{cm}^{2}\right.$ for $3 \mathrm{~s}, 1$-min delay, followed by $700 \mathrm{~mW} / \mathrm{cm}^{2}$ for $20 \mathrm{~s}$ ) presented the highest bond strength of all groups, and Knoop hardness similar to that of the other groups.

\section{RESUMO}

Este estudo verificou a resistência de união e a dureza Knoop do compósito Z250 (3M/ESPE), fotoativado com luz de lâmpada halógena (XL2500,3M/ESPE), utilizando diferentes protocolos: modo contínuo - alta intensidade $(\mathrm{CH})\left(700 \mathrm{~mW} / \mathrm{cm}^{2}\right)$ por $20 \mathrm{~s}$; modo contínuo - baixa intensidade $(\mathrm{CL})\left(150 \mathrm{~mW} / \mathrm{cm}^{2}\right)$ por $20 \mathrm{~s}$; pulse-delay com $150 \mathrm{~mW} / \mathrm{cm}^{2}$ por 2(P2), 3(P3), 5(P5), 10(P10) ou 15(P15) segundos, com 1 min de espera, seguido por $700 \mathrm{~mW} /$ $\mathrm{cm}^{2}$ por 20 s. Para o teste de união push-out $(\mathrm{n}=10)$, os valores de resistência de união foram obtidos em máquina de ensaio universal Instron. Para o ensaio de dureza Knoop $(n=5)$ os espécimes foram fotoativados pelos mesmos protocolos utilizados no ensaio de resistência de união. As medidas de dureza foram realizadas em um microdurômetro (Shimadzu) em 6 profundidades (topo, $1,2,3,4$ e $5 \mathrm{~mm}$ ). Os dados foram submetidos à Análise de Variância e ao teste de Tukey com nível de significância de 5\%. Os resultados mostraram que P5 e CL apresentaram resistência de união estatisticamente superior a todos os grupos. Não houve diferença entre os grupos P2, P3, P10, P15 e CH. Para dureza Knoop, $\mathrm{CH}$ apresentou os maiores valores, estatisticamente superiores a P2 e CL até $4 \mathrm{~mm}$. A partir de $3 \mathrm{~mm}$, a dureza de todos os grupos foi inferior a dureza do topo. O tempo de exposição inicial para o modo pulse-delay pode influenciar a resistência de união e a dureza Knoop.

\section{REFERENCES}

1. Byerley TJ, Eick JD, Chen GP, Chappelow CC, Millich F. Synthesis and polymerization of new expanding dental monomers. Dent Mater 1992;8:345-350.

2. Feilzer AJ, De Gee AJ, Davidson CL. Setting stress in composite resin in relation to configuration of the restoration. J Dent Res 1987;66:1636-1939.

3. Peutzfeldt A, Sahafi A, Asmussen E. Characterization of resin composites polymerized with plasma arc curing units. Dent Mater 2000;16:330-336.

4. Obici AC, Sinhoreti MA, de Goes MF, Consani S, Sobrinho LC. Effect of the photo-activation method on polymerization shrinkage of restorative composites. Oper Dent 2002;27:192-198.

5. Geurtsen W. Substances released from dental resin composites and glass ionomer cements. Eur J Oral Sci 1998;106:687-695.

6. Koran P, Kurschner R. Effect of sequential versus continuous irradiation of a light-cured resin composite on shrinkage, viscosity, adhesion, and degree of polymerization. Am J Dent 1998;11:17-22.

7. Dall'magro E, Sinhoreti MA, Correr AB, Correr-Sobrinho L, Consani S, Puppin-Rontani RM. Effect of different initial light intensity by the soft-start photoactivation on the bond strength and Knoop hardness of a dental composite. Braz Dent J 2007;18:107-112.

8. Roydhouse RH. Punch-shear test for dental purposes. J Dent Res 1970;49:131-136.

9. Frankenberger R, Sindel J, Kramer N, Petschelt A. Dentin bond strength and marginal adaptation: direct composite resins vs ceramic inlays. Oper Dent 1999;24:147-155.

10. Correr AB, Sinhoreti MA, Correr-Sobrinho L, Tango RN, Schneider LF, Consani S. Effect of the increase of energy density on knoop hardness of dental composites light-cured by conventional QTH, LED and xenon plasma arc. Braz Dent J $2005 ; 16: 218-224$.

11. Visvanathan A, Ilie N, Hickel R, Kunzelmann KH. The influence of curing times and light curing methods on the polymerization shrinkage stress of a shrinkage-optimized composite with hybrid-type prepolymer fillers. Dent Mater 2007;23:777-784.

12. Sakaguchi RL, Wiltbank BD, Murchison CF. Contraction 
force rate of polymer composites is linearly correlated with irradiance. Dent Mater 2004;20:402-407.

13. Alonso RC, Cunha LG, Correr GM, Cunha Brandt W, CorrerSobrinho L, Sinhoreti MA. Relationship between bond strength and marginal and internal adaptation of composite restorations photocured by different methods. Acta Odontol Scand 2006;64:306-313.

14. Braga RR, Ballester RY, Ferracane JL. Factors involved in the development of polymerization shrinkage stress in resincomposites: a systematic review. Dent Mater 2005;21:962970.

15. Kanca J 3rd, Suh BI. Pulse activation: reducing resin-based composite contraction stresses at the enamel cavosurface margins. Am J Dent 1999;12:107-112.

16. Asmussen E, Peutzfeldt A. Influence of composition on rate of polymerization contraction of light-curing resin composites. Acta Odontol Scand 2002;60:146-150.
17. Yap AU, Soh MS, Siow KS. Post-gel shrinkage with pulse activation and soft-start polymerization. Oper Dent 2002;27:81-87.

18. Halvorson RH, Erickson RL, Davidson CL. Energy dependent polymerization of resin-based composite. Dent Mater 2002;18:463-469.

19. Schneider LF, Moraes RR, Cavalcante LM, Sinhoreti MA, Correr-Sobrinho L, Consani S. Cross-link density evaluation through softening tests: effect of ethanol concentration. Dent Mater 2008;24:199-203.

20. Goncalves F, Calheiros FC, Witzel MF, Kawano Y, Braga RR. Effect of photoactivation protocol and radiant exposure on monomer conversion and flexural strength of a resin composite after water and ethanol storage. J Biomed Mater Res B Appl Biomater 2007;82:89-92.

Accepted September 11, 2008 